\title{
Field performance and screening for resistance to Peronospora destructor of 46 onion cultivars in Brazil
}

\author{
Daniel Pedrosa Alves ${ }^{1}$ (D) • Edivânio Rodrigues de Araújo ${ }^{1}$ • Gerson Henrique Wamser ${ }^{1}$. \\ Paulo Antônio de Souza Gonçalves ${ }^{1} \cdot$ Caillet D. Marinho ${ }^{2} \cdot$ Rafael Simões Tomaz $^{3}$
}

Received: 22 October 2017 / Accepted: 20 February 2018 / Published online: 3 March 2018

(C) Australasian Plant Pathology Society Inc. 2018

\begin{abstract}
This work evaluated the field performance and resistance to Peronospora destructor of 46 onion cultivars in two different experiments. Two open-pollinated experimental cultivars: "Bola Precoce-Agroecológica, and "Superprecoce-Agroecológica" were more productive and resistant. The onion breeding by screenings in agroecological production systems may be an alternative to obtain germplasm less sensitive to biotic and abiotic stresses.
\end{abstract}

Keywords Adaptability $\cdot$ Allium cepa $\cdot$ Downy mildew $\cdot$ Local cultivars $\cdot$ Plant breeding

Onion (Allium cepa) is an important vegetable crop grown all over the world. It is the third most economically important vegetable in Brazil, with an estimated production value of BRL 1.81 billion (approximately US\$ 600 million) in 2015 (IBGE 2017). The southern region of Brazil concentrates about $33 \%$ of this production value. Despite the intensive cultivation of onion in this region, two factors can significantly limit yield: (i) the high occurrence and severity of downy mildew; (ii) and use of cultivars not adapted.

Onion downy mildew, caused by Peronospora destructor, has global occurrence and becomes more relevant in temperate regions (Domingues and Tofoli 2009). According to Wordell Filho and Boff (2006), downy mildew is one of the main onion diseases in southern Brazil. van der Meer and de Vries (1990) reported complete resistance to downy mildew found in Allium roylei. Kofoet et al. (1990) determined that the inheritance of resistance was due to a single dominant gene, $P d 1$. However, to date, there is no resistant commercial cultivar in Brazil.

Daniel Pedrosa Alves

danielalves@epagri.sc.gov.br

1 Empresa de Pesquisa Agropecuária e Extensão Rural de Santa Catarina - Epagri/Estação Experimental de Ituporanga, Estrada Geral Lageado Águas Negras, 453, Ituporanga, SC 88400-000, Brazil

2 Helix Seed (Agroceres), Patos de Minas, MG, Brazil

3 FCAT, Universidade Estadual Paulista "Júlio de Mesquita Filho" (UNESP), Dracena. Rod. Cmte João Ribeiro de Barros. km 651, Dracena, SP 17900-000, Brazil
The use of onion cultivars not adapted to a particular region may hinder the formation of bulbs, reducing the yield. There are 437 onion cultivars registered and four protected cultivars in Brazil (MAPA 2017). This paper aimed to evaluate the field performance of 46 onion cultivars in the southern region of Brazil, as well as evaluate the severity and yield loss caused by downy mildew.

Thirty-one commercial open-pollinated (OP) onion cultivars, eight experimental hybrids, two commercial hybrids, and five experimental OP cultivars originated by mass selection in agroecological systems (both during the bulb and the seed production phases) were evaluated in two different experiments. The identification of the cultivars is presented in Table 1 .

The experimental OP cultivar denominated "Poranga Agroecológica" was originated from "SCS366 Poranga" for two complete cycles in agroecological systems. The following cultivars were selected in five complete cycles in the agroecological system: cv. "Superprecoce - Agroecológico" originated from Epagri 363 Superprecoce"; "Bola Precoce Agroecológica" originated from "Empasc 352 Bola Precoce"; "Juporanga - Agroecológica" from "Empasc 355 Juporanga" and "Crioula Alto Vale -Agroecógica" from "Epagri 362 Crioula Alto Vale".

Onion seedlings were grown on soil bed and approximately 60 days after sowing, they were transplanted to the two experiments that remained from July to December in 2015. The light hours required by cultivars of short or intermediate days were considered for the accomplishment of the sowing and transplantation. The experimental design of both experiments 


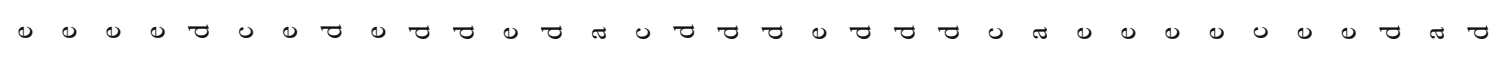

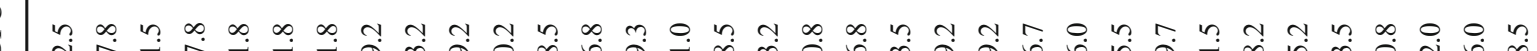
तु่

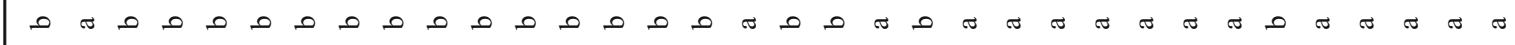

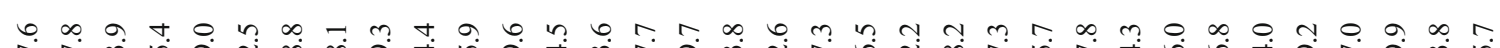

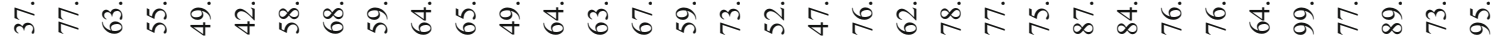

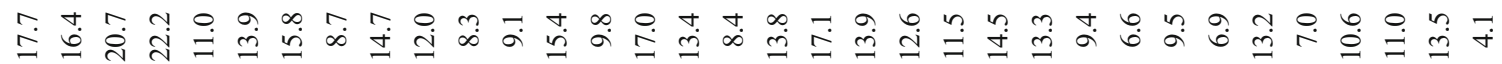

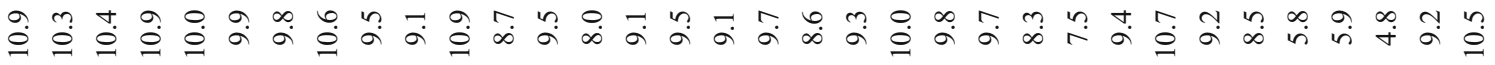

¿

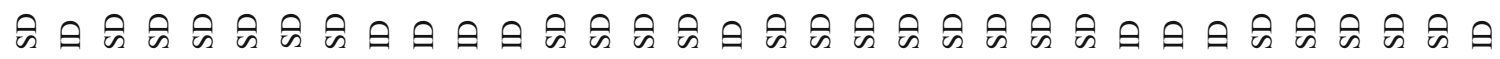

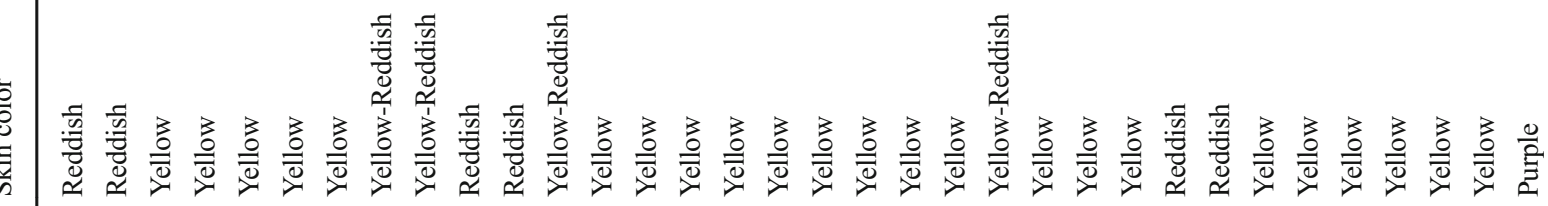

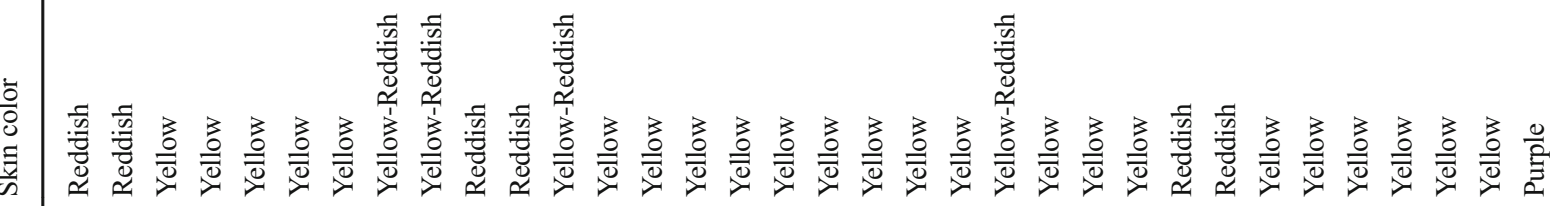

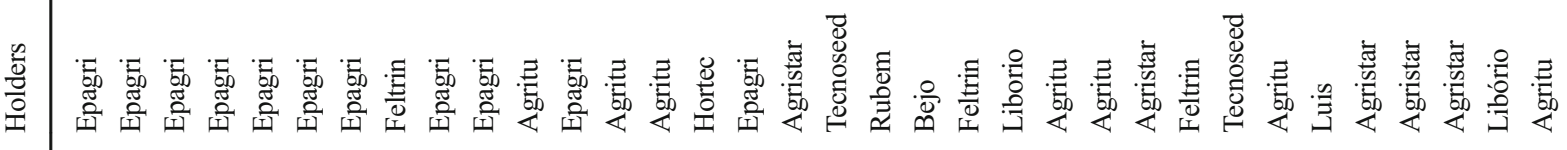
$\sum_{\substack{0 \\:}}^{0}$

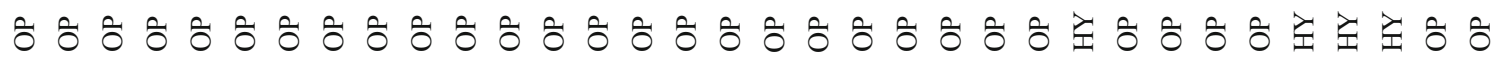

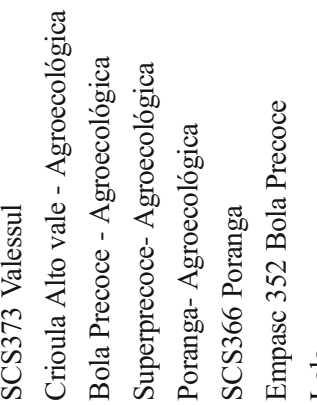

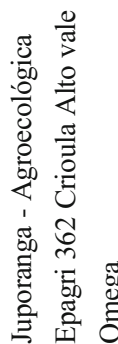

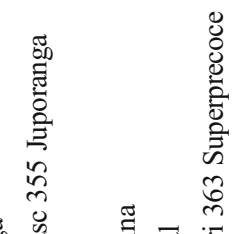




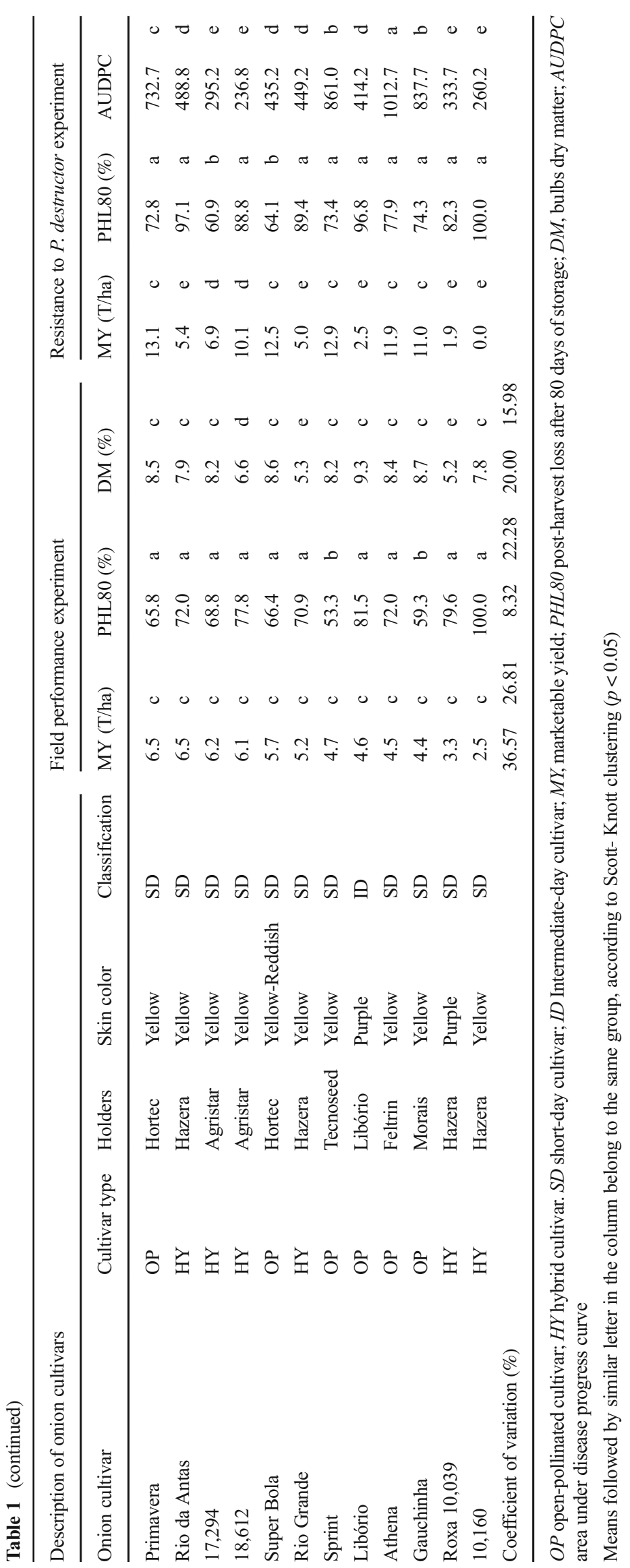


was in randomized blocks, with three replicates. The experiments were conducted in Ituporanga, SC - Brazil, at $475 \mathrm{~m}$ altitude, $27^{\circ} 22^{\prime} \mathrm{S}$ of latitude and $49^{\circ} 35^{\prime} \mathrm{W}$ of longitude, in dystrophic humic cambium soil. Each experimental plot (138 plots per experiment) had 120 plants (six lines with 20 plants), arranged in a spacing of $35 \mathrm{~cm}$ between rows and $7.5 \mathrm{~cm}$ between plants. We evaluated the 88 useful plants of the central area of each plot.

Experiment 1 - Field performance experiment - Cultural practices were performed as recommended by EPAGRI (n.d.). Seven-day intervals sprays of systemic and protective fungicides started approximately 25 days after the transplant of each cultivar. Besides, four insecticides sprays were applied. The following variables were evaluated: i) marketable yield (MY), in which only healthy bulbs and that had a diameter equal or greater than $35 \mathrm{~mm}$ were quantified; ii) post-harvest loss, in which the percentage of loss was measured in relation to the initial weight of the marketable bulbs that maintained this pattern after 80 days of storage (PHL80); iii) and percentage of dry matter (\%DM), analysed following the protocol presented by Pozzo Ardizzi et al. (2005).

Experiment 2 - Resistance to Peronospora destructor experiment - The trial was performed without chemical control of foliar diseases after transplantation. Downy mildew epidemics occurred due to natural infection. The severity of the disease was evaluated weekly, beginning 30 days after transplantation. The severity was rated for each plot using a rating description scale (1-9), which assigns notes to the entire plot (Mohibullah, 1991). The values from scale notes of the experimental plots were used to calculate the area under disease progress curve AUDPC (Shaner and Finney 1977). In addition, the evaluation also included: MY, and PHL80 according to the field performance experiment. To allow reproducibility of the assay, sporangia and sporangiophores from local populations of $P$. destructor were stored in the Phytosanitary Laboratory at Epagri/EEITU (code EITF 20), according to the preservation technique of freeze-drying (Laviola et al. 2006).

The variables were analyzed using ANOVA and, in case of significance of the treatments indicated by the $\mathrm{F}$ test $(p<0.05)$, means were grouped with Scott-Knott cluster analysis $(p=0.05)$. The analyses were performed using computational software GENES® (Cruz, 2013).

Experiment 1: Field performance experiment: for the MY variable, three groups were formed. The group with the highest averages (16.13 to 26.47 ton/ha) was composed of 12 cultivars, all OP, which 11 were developed in the region of the experiment (Table 1). Nine out of the ten hybrids evaluated were in the group with the lowest averages ( 2.54 to 8.38 ton/ha). PHL80 formed only two groups, the group of cultivars with the highest losses at 80 days of storage had cultivars with losses between $62.10 \%$ and $100 \%$. In the second group, cultivars had losses between $23.65 \%$ and $59.32 \%$. For the variable \%DM, five groups were formed. Eight OP cultivars were in the group with the highest \%DM (10.93 to 10.27), while five hybrid cultivars were in the group with the lowest $\% \mathrm{DM}$ (4.81 to 5.94).

Experiment 2: Resistance to Peronospora destructor experiment: the mean of AUDPC was divided into five groups. In the group with the highest averages (1012.67 to 1106.00) were four cultivars, all open-pollinated and short-day. The lowest averages (187.83 to 358.17$)$ were observed in 18 cultivars, including three OP experimental cultivars: "Superprecoce Agroecológica", "Bola Precoce - Agroecológica" and "Crioula Alto Vale - Agroecológica" (Table 1). For the MY variable, five groups were formed. Among the highest averages (20.74 and 22.24 ton/ha), again were the cultivars "Superprecoce - Agroecológica" and "Bola Precoce Agroecológica". The PHL80 formed two groups, in which 25 cultivars formed the group with the highest losses (72.77 to $100 \%$ ), and the others were allocated within the group that had losses varying from 37.62 to $68.06 \%$.

The low yield performance of the hybrid cultivars in both experiments suggests low adaptability to the edafo-climatic conditions of southern Brazil. This can be partially explained by the origin of the germplasm used as the parent of the hybrid cultivars. The hybrids evaluated in the present experiments come from multinational companies which often have their breeding programs in regions with a very distinct weather compared to the southern Brazil. According to Osman et al. (2008), each breeding company has gathered local selections and those form the basis of their hybrid breeding programs. However, it seems that the genetic base used to constitute the hybrids is not adapted to the conditions of southern Brazil. Pike (1986) said that open-pollinated cultivars continue to have a place because they do not have such a narrow genetic base as hybrids and may prove to be better adapted to the environmental stresses that occur in many areas of production. On the other hand, the use of hybrid cultivars predominates in the southeastern and central regions of Brazil, where the weather is more similar to regions where hybrid cultivars are developed.

None of the hybrid cultivars were classified in the groups with higher mean AUDPC. However, the lower severity of the disease did not resulted higher yields, contrariwise, hybrid cultivars were always among the less productive. This observation is more evident when we analyse the hybrids performance in the field performance experiment. Further studies are needed to determine if the lower severity of the disease is due to some level of resistance or no preference of pathogen for less developed plants and lower leaf area.

We observed the interaction of the cultivars in the two environments-experiments (Fig. 1). The hybrid cultivars were located in the lower left quadrant, showing low performance in both experiments. On the other hand, four OP cultivars were more productive in both experiments, and were located in the upper right quadrant. In general, it was observed that the 


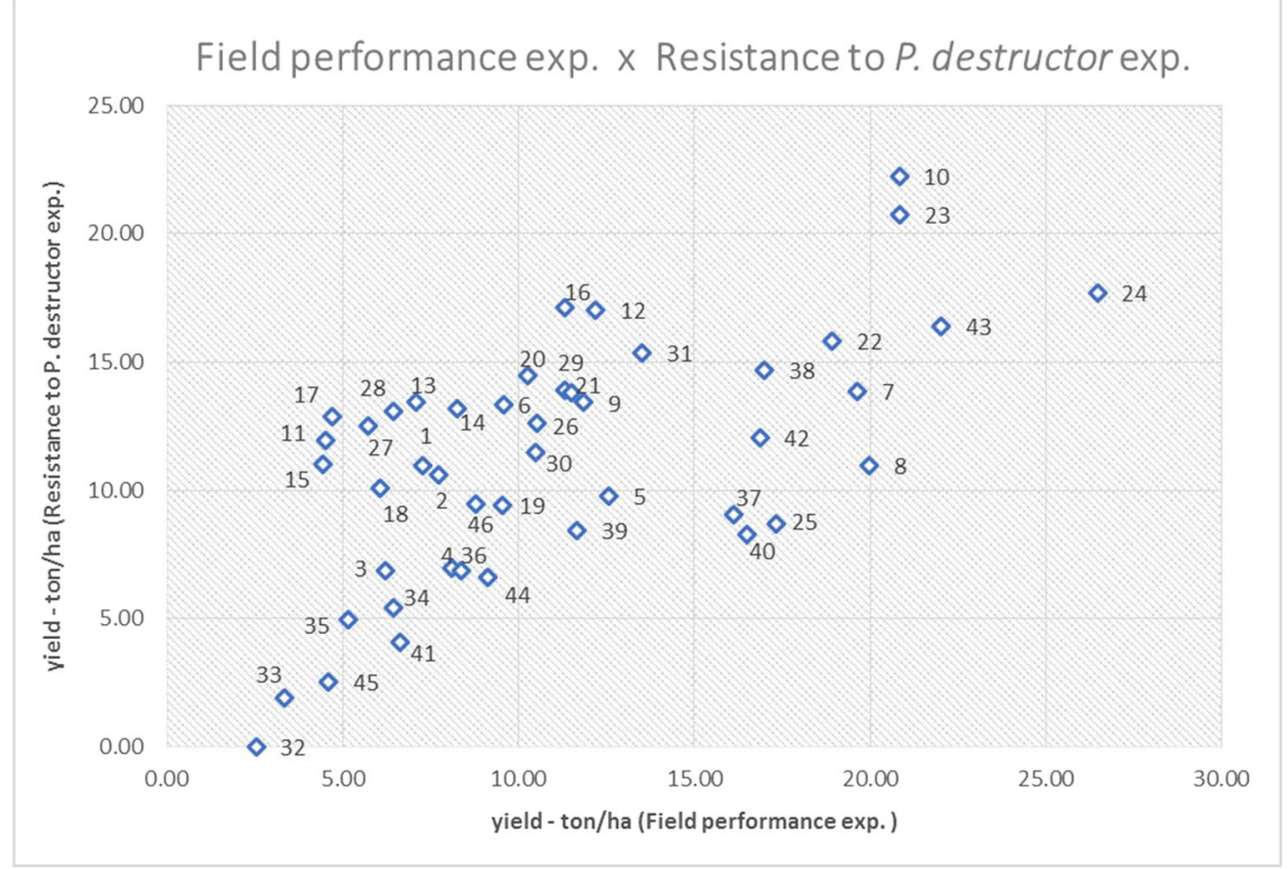

Fig. 1 Genotype-Environment interactions for yield of the 46 cultivars in field performance and resistance to Peronospora destructor experiments. The numbers of blue diamonds represent: $1=$ cultivar " 425 ", $2=560$; $3=17,294 ; 4=8706 ; 5=$ Catarina; $6=$ Menina; $7=$ SCS366 Poranga; $8=$ Poranga - Agroecológica; $9=$ Epagri 363 Superprecoce; $10=$ Superprecoce - Agroecológica; $11=$ Athena; $12=$ Boreal; $13=$ Preciosa; $14=$ Sentinela; $15=$ Gauchinha; $16=$ RDW Luthy; $17=$ Sprint; $18=$ 18,$612 ; 19=564 ; 20=$ Rainha; $21=$ Thesis; $22=$ Empasc 352 Bola

cultivars had no differential response to the different environments. Therefore, for our assays, the productivity does not depend on the experiment.

Some OP cultivars were less damaged by downy mildew and presented satisfactory yield performance, citing the commercial cultivars SCS373 Valessul and Empasc 352 Bola Precoce, besides the breeding populations Superprecoce Agroecológica, Bola Precoce - Agroecológica and Crioula Alto Vale Agroecológica. Colnago et al. (2012) evaluated the response of 40 local germplasms from Uruguay to the natural infection with $P$. destructor and reported greater resistance to the pathogen in long-day cultivars. In the present work, we did not evaluate long day cultivars, however, six out of the 11 intermediate-day cultivars evaluated were allocated within the group with lower AUDPC means. According to Colnago et al. (2012), the severity differential response can be partially explained by: i) different mechanisms involved in the partial resistance that can cause a delay in the installation as in the progression rate of the disease; ii) structural defences of the plant, such as leaf waxiness of the cultivars, which could prevent the formation of a continuous water film. The duration of the leaf wetting period is fundamental for the infection process by $P$. destructor (Hildebrand and Sutton 1982; Schwartz and Mohan 2008). For Brazilian conditions, the present study is the first to report contrasting severity, caused precoce; 23 = Bola precoce - Agroecológica; $24=$ SCS373 Valessul; $25=$ Lola; $26=$ Baia Herval; $27=$ Super Bola; $28=$ Primavera $; 29=$ Bola Suprema; $30=$ Pampeana; $31=$ Onix; $32=10,160 ; 33=$ Roxa 10,$039 ; 34=$ Rio da Antas; $35=$ Rio Grande; $36=$ Dourada; $37=$ Empasc 355 Juporanga; 38 = Juporanga - Agroecológica; 39= BR25; $40=$ Omega $; 41=$ Caeté; $42=$ Epagri362 Crioula Alto vale; $43=$ Crioula Alto Vale - Agroecológica; $44=$ Conesul; $45=$ Libório; $46=$ Mulata

by downy mildew, for onion cultivars. Carré-Missio et al. (2011), when evaluating nine onion cultivars in Brazil, did not observe significant differences for downy mildew severity.

A hypothesis for the lowest severity observed in experimental OP cultivars developed in the agroecological system would be transgenerational systemic acquired resistance (SAR). Lunna and Ton (2012) called "transgenerational SAR" the resistance in progeny that, according to the authors, requires non expressor of PR genes (NPR1) and is associated with priming of SA-inducible defence genes. Lunna et al. (2012) demonstrated that progeny from Pseudomonas syringae pv. tomato DC3000-infected Arabidopsis (P1 progeny) are primed for SA-dependent defence compared with progeny from control-treated healthy plants (C1 progeny). According to these authors, this type of resistance is effective against (hemi)-biotrophic pathogens. However, this is only a hypothesis and further studies are needed to establish whether these cultivars have a true resistance mechanism or the result of primed defenses.

Schwartz and Mohan (2008) reported that in plants infected with downy mildew, besides the loss in productivity, there is also loss in bulb quality. In addition, infected bulbs easily soften, wither, and sprout prematurely during storage. Lee et al. (2016) found a negative correlation between percentage of dry matter and losses during cold storage $\left(0 \pm 1{ }^{\circ} \mathrm{C}\right)$ in 
healthy bulbs. According to these authors, cultivars with higher levels of dry matter tend to have lower losses during the storage. This fact was similar to that observed in the present study, since the hybrid cultivars composed groups with the lowest \%DM mean and the larger PHL80. According to Galmarini et al. (2001) and Lee et al. (2012), the \%DM also presents positive correlation with total soluble solids. Platenius and Knott (1941) reported that \%DM is also linked to onion pungency, main component of aroma and flavour in onion. Cultivars that are in the group with the highest \%DM means can be used in breeding programs aimed at processing and longer storage cultivars, while the cultivars that belong to the groups with lower \%DM means can be used in onion sweet breeding programs for in natura consumption and commerce without storage.

According to the present study, it was possible to select and indicate the OP experimental cultivars Superprecoce Agroecológica and Bola Precoce - Agroecológica as future commercial cultivars. These two cultivars composed the groups with higher YM and lower PHL80. In addition, these populations have higher \%DM and presented lower severity caused by downy mildew.

Acknowledgments This work was supported by Conselho Nacional de Desenvolvimento Científico e Tecnológico (CNPq - 449218/2014-7); and Empresa de Pesquisa Agropecuária e Extensão Rural de Santa Catarina (Epagri).

\section{References}

Carré-Missio V, Lannes SD, Marcuzzo LL (2011) Resistência de genótipos de cebola à míldio (Peronospora destructor). In Tropical Plant Pathology 36 (Suplemento). XLIV Congresso Brasileiro de Fitopatologia - Bento Gonçalves RS p 1044

Colnago P, González P, Noguez M, Bentancur O, Galván GA (2012) Evaluación de la respuesta a Peronospora destructor (Berk.) Casp. en el germoplasma local de cebolla en Uruguay. Agroc Uruguay 16: 33-44

Cruz CD (2013) GENES - a software package for analysis in experimental statistics and quantitative genetics. Acta Sci 35:271-276

Domingues RJ, Töfoli JG (2009) Míldio da cebola: importância, identificação e métodos de controle. Biológico, São Paulo 71:29-31

EPAGRI. (n.d.) Sistema de produção para a cebola: Santa Catarina. (4. Revisão). Florianópolis: 2013. 106p. (Epagri. Sistema de Produção, 46)

Galmarini CR, Goldman IL, Havey MJ (2001) Genetic analyses of correlated solids, flavor, and health-enhancing traits in onion (Allium cepa L.) Mol Gen Genomics 265:543-551

Hildebrand PD, Suton JC (1982) Weather variables in relaton to an epidemic of onion downy mildew. Phytopathology 72:219-224
IBGE, Sistema IBGE de recuperação automática (SIDRA) (2017) http:// www.sidra.ibge.gov.br/bda/tabela/protabl.asp?c=1612\&z=t\&o= $1 \& \mathrm{i}=$ P. Accessed August 2017

Kofoet A, Kik C, Wietsma WA, de Vries JN (1990) Inheritance of resistance to downy mildew (Peronospora destructor [Berk.] Casp.) from Allium roylei Stearn in the backcross Allium cepa $\mathrm{L}$. $\mathrm{x}$ (A. roylei x A. cepa). Plant Breed 105:144-149

Laviola C, Cannizzaro G, Conigliaro G, Burruano S (2006) Simple techniques for long-term storage of Plasmopara viticola. Phytopathol Mediterr 45:271-275

Lee JT, Kim HD, Lee SD, Ro CH (2012) Variability and interrelationship among yield and bulb quality contributing characters in intermediateday onion. Acta Hortic 969:123-131

Lee J, Ha I, Kim H, Choi S, Lee S, Kang J, Boyhan GE (2016) Regional Differences in Onion Bulb Quality and Nutrient Content, and the Correlation Between Bulb Characteristics and Storage Loss. Korean J Hortic Sci Technol 34:807-817

Lunna E, Ton J (2012) The epigenetic machinery controlling transgenerational systemic acquired resistance. Plant Signal Behav 7:615-618

Lunna E, Bruce TJA, Roberts MR, Flors V, Ton J (2012) Nextgeneration systemic acquired resistance. Plant Physiol 158:844-853

MAPA, Ministério da Agricultura Pecuária e Abastecimento. CultivarWeb. (2017) http://extranet.agricultura.gov.br/php/snpc/ cultivarweb/cultivares_registradas.php. Accessed August 2017

Mohibullah (1991) Studies on major disease of bulb vegetables (onion and garlic) in N.W.F.P. Province, Pakistan. Final Technical Report (October 1986 to September 1991). Agricultural Research Institute Tarnab (Peshawar) NWFP Pakistan

Osman AM, Almekinders CJM, Struik PC, Lammerts van Bueren ET (2008) Can conventional breeding programmes provide onion varieties that are suitable for organic farming in the Netherlands? Euphytica 163:511-522

Pike LM (1986) Onion Breeding. In: Bassett MJ (ed) Breeding Vegetable Crops. AVI Publishing, Westport, Conn, pp 357-394

Platenius H, Knott JE (1941) Factors affecting onion pungency. J Agric Res 62:371-380

Pozzo Ardizzi MC, Arbrameto M, Pellejero G, Aschkar G, Gil MI, Van Konijnemburg A (2005). Efecto del período de conservación sobre algunas propriedades nutracéuticas y organolépticas em os bulbos de cultivares nacionales de cebolla (Allium cepa L.) em el Valle Inferior de Rio Negro. Revista de Investigaciones Agropecuarias 34: $115-130$

Schwartz HF, Mohan SK (2008) Compendium of onion and garlic diseases and pests, 2nd edn. APS Press, St Paul

Shaner G, Finney RE (1977) The effect of nitrogen fertilization on the expression of slow-mildewing resistance in Knox wheat. Phytopathology 67:1051-1056

van der Meer QP, de Vries JN (1990) An interspecific cross between Allium roylei Stearn and Allium cepa L., and its backcross to A. cepa. Euphytica 47:29-31

Wordell Filho JA, Boff P (2006) Doenças de origem parasitária. In: Wordell Filho JA, Rowe E, Gonçalves PAS, Debarba JF, Boff P, Thomazelli LF (eds) Manejo Fitossanitário na Cultura da Cebola. Florianópolis, Epagri, pp 19-162 